\title{
Medicinal Plants as Potential Hemostatic Agents
}

\author{
Fatemeh Ebrahimi $^{\text {a }}$, Mohammadali Torbati ${ }^{\text {b,a }}$, Javad Mahmoudic, Hadi Valizadeh ${ }^{\mathrm{d}}$ \\ ${ }^{a}$ School of Traditional Medicine, Tabriz University of Medical Sciences, Tabriz, Iran. ${ }^{\mathrm{b}}$ Department of Food Science and \\ Technology, Faculty of Nutrition, Tabriz University of Medical Sciences, Tabriz, Iran. ${ }^{\mathrm{c}}$ Neurosciences Research Center \\ (NSRC), Tabriz University of Medical Sciences, Tabriz, Iran. ${ }^{d}$ Department of Pharmaceutics, Faculty of Pharmacy, Tabriz \\ University of Medical Sciences, Tabriz, Iran.
}

Received, October 31, 2019; Revised, November 15, 2019; Accepted, January 31, 2020; Published, February 2, 2020.

\begin{abstract}
Purpose: Medicinal plants with a variety of phytochemical ingredients remain a potential source for new drug discovery. The use of medicinal herbs in a wide range of diseases and symptoms, such as bleeding, is prevalent in traditional and ethno medicine worldwide. Thus, this work provides a comprehensive review of medicinal plants or their isolated compounds, with respect to their ethno-medicinal use, which have demonstrated the stimulating effect on the hemostasis process. Methods: The relevant studies were withdrawn from electronic databases including Pubmed, EMBASE and Web of Science with a structured search methodology. Results: The total of 17 medicinal plants with hemostatic activity were extracted. The most frequently studied plant families were Compositae, Lamiaceae, Fabaceae, and Asteraceae. Bioactive compounds exerting hemostatic activity included tannins, iridoid glycosides, glycoconjugate, lignan, saponins and phenolic compounds. The most attributed mechanisms include coagulation stimulation via increasing the factor XII activity and plasma fibrinogen levels, the fibrinolysis inhibition, vascular or smooth muscle constriction and platelet aggregation. The most important adverse effects of high dose extract or isolated compounds administration were hepatotoxicity and nephrotoxicity. Conclusion: This review provides a list of medicinal plants with hemostatic activity that could be used as valuable sources of new plant-based hemostatic agents. Furthermore, this could be practical in detecting possible interactions of plants with anticoagulant, antiplatelet, fibrinolytic and antifibrinolytic medications.
\end{abstract}

\section{INTRODUCTION}

The early bleeding control is essential, since blood is the valuable essence of life and uncontrolled hemorrhage could lead to the survival- threatening conditions (1). The natural hemostatic system of the body is able to manage the mild to moderate bleedings. It comprises of three successive stages: vasoconstriction, platelet plug formation, and blood coagulation (2). Upon the completion of coagulation the cross-linked fibrin meshes create the clot and seals the injured vessel. Alongside with the coagulation pathway the fibrinolytic system is activated to prevent the inclement formation of fibrin clots. Accordingly, the balance between the fibrinolysis and hemostasis is important for the proper control of hemorrhage (3). Following a vascular damage platelets are activated by contact to the endothelial proteins. Subsequently, the coagulation initiates and proceeds through the serial enzymatic reactions, leading to the conversion of zymogen prothrombin to thrombin. Insoluble fibrin is finally generated by the catalytic activity of thrombin on soluble fibrinogen (4). Ensuing the hemostasis the fibrinolytic system is activated by tissue plasminogen activator (tPA) or urokinase, which generates the plasmin from its zymogen form plasminogen. Any disruption in the regular mechanisms of coagulation and fibrinolytic systems could affect the normal hemostasis $(3,5)$.

Hemostatic agents can act through clotting factor activation, vasoconstriction, platelet aggregation, or ant-fibrinolytic activity. Unfortunately, none of the available hemostatic agents are perfect and each has their own defects. For instance, biological agents, fibrin and thrombin, are expensive and potential to transfer viral infections, because they are derived from the human or bovine blood $(6,7)$. Aprotinin is an anti-fibrinolytic agent and may cause side effects due to the non-specific serine protease inhibitory effects and in some cases, serious anaphylactic shock may occur because of its biological nature $(8,9)$.

Therefore, finding new effective hemostatic agents with less adverse effects and disadvantages

Corresponding Author: Mohammadali Torbati, ${ }^{\text {a }}$ School of Traditional Medicine, Tabriz University of Medical Sciences, Tabriz, Iran; Email: torbatim@,tbzmed.ac.ir 
seems to be substantial. Since the use of herbal medicines is getting popular worldwide (10) and with respect to the long history of ethno-medicinal use of plants in bleeding control, it would be an invaluable source of finding new hemostatic drugs. To the best of our knowledge there is no comprehensive review of the plants' stimulating effects on hemostasis process. Only one study has discussed the herbal remedies effect on the coagulation cascade and is mostly focused on the anticoagulant effects of the plants. The aim of this review is to provide a list of plants with stimulating effect on hemostasis and describe their active constituents as well as possible involved mechanisms.

\section{METHODS}

Electronic databases including Pubmed, Embase and Web of Science were searched for the medicinal plants which exerted the hemostatic activity, till October 2018. The search terms were "plant" or "extract" or "herb" and "hemostasis" or "blood coagulation" or "bleeding". Only English-language article with available full text which evaluated the hemostatic activity of the crude extract or the isolated phytochemicals were included. Moreover, review articles, congress abstracts, and articles that investigated the effect of plant combinations or plant based preparations were excluded. Also, articles indicating the hemostatic activity of plant proteases were excluded. After the article selection process 25 articles were chosen for the review. A summary of study selection design is shown in figure 1 .

\section{RESULTS}

\section{Medicinal plants and their bioactive constituents with hemostatic properties}

In this section the medicinal plants and phytochemicals with a stimulating effect on hemostatic parameters are discussed. The scientific name and family of the plant, the ethno-medicinal use, the experimental methods, involved mechanisms and potential side effects are briefly included in each monograph. Table 1 represents the in vitro, in vivo, and clinical studies of hemostatic plants. Studies on phytochemicals with hemostatic bioactivities are presented in table 2 .

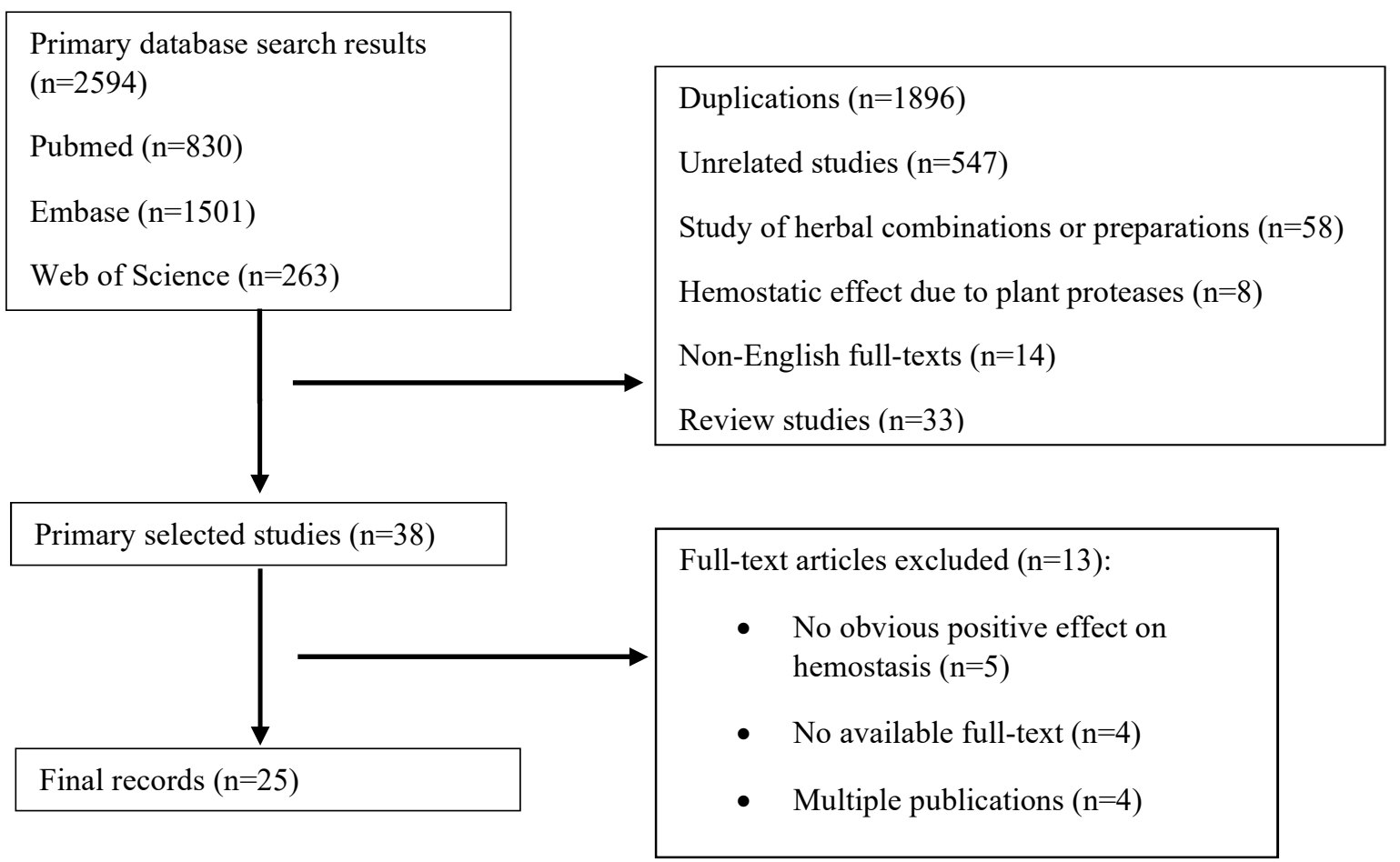

Figure 1. Summary of study selection design. 
Table 1. In vitro, in vivo and clinical studies on medicinal plants having stimulating effects on hemostasis

\begin{tabular}{|c|c|c|c|c|c|c|}
\hline Plant & Family & $\begin{array}{l}\text { Parts } \\
\text { used and } \\
\text { preparation }\end{array}$ & Study Type & Results & $\begin{array}{l}\text { Related } \\
\text { ethnomedicinal } \\
\text { uses if stated }\end{array}$ & References \\
\hline \multirow[t]{4}{*}{$\begin{array}{l}\text { Ageratum } \\
\text { conyzoides } \mathrm{L} .\end{array}$} & \multirow[t]{4}{*}{ Asteraceae } & \multirow[t]{2}{*}{$\begin{array}{l}\text { Ethanolic } \\
\text { leaf extract }\end{array}$} & In vivo (mice) & $\downarrow$ Clotting time & \multirow[t]{4}{*}{$\begin{array}{l}\text { Wound healing, } \\
\text { hemostatic }\end{array}$} & \multirow[t]{2}{*}{ (11) } \\
\hline & & & In vitro & $\downarrow$ Bleeding time & & \\
\hline & & $\begin{array}{l}\text { Methanolic } \\
\text { leaf extract }\end{array}$ & In vivo (rat) & $\downarrow$ Bleeding time & & \multirow[t]{2}{*}{$(12)$} \\
\hline & & & In vitro & $\begin{array}{l}\downarrow \text { PT } \\
\downarrow \text { Clotting time } \\
\uparrow \text { Plasma fibrinogen }\end{array}$ & & \\
\hline $\begin{array}{l}\text { Artemisia } \\
\text { annua } \mathrm{L} \text {. }\end{array}$ & Asteraceae & $\begin{array}{l}\text { n-butanol } \\
\text { extract of } \\
\text { whole plant }\end{array}$ & In vitro & $\downarrow$ Clotting time & Hemostatic & (13) \\
\hline $\begin{array}{l}\text { Brownea } \\
\text { grandiceps } \\
\text { Jacq. }\end{array}$ & Fabaceae & $\begin{array}{l}\text { Aqueous } \\
\text { flower } \\
\text { extract }\end{array}$ & In vitro & $\begin{array}{l}\downarrow \mathrm{PT} \& \text { anti-fibrinolytic } \\
\text { activity at low con. } \\
\uparrow \mathrm{PT}, \uparrow \text { aPTT, } \uparrow \text { TT and } \\
\text { FXa inhibition at high con. }\end{array}$ & Hemostatic & (14) \\
\hline $\begin{array}{l}\text { Camellia } \\
\text { sinensis (L.) } \\
\text { Kuntze }\end{array}$ & Theaceae & $\begin{array}{l}\text { Ethanolic } \\
\text { leaf extract }\end{array}$ & Clinical & $\begin{array}{l}\downarrow \text { Bleeding after tooth } \\
\text { extraction }\end{array}$ & Hemostatic & $(15)$ \\
\hline $\begin{array}{l}\text { Capsella bursa- } \\
\text { pastoris (L.) }\end{array}$ & Brassicaceae & $\begin{array}{l}\text { Hydro- } \\
\text { alcoholic } \\
\text { extract of } \\
\text { whole plant }\end{array}$ & Clinical & $\downarrow$ Postpartum hemorrhage & Hemostatic & $(16)$ \\
\hline $\begin{array}{l}\text { Chromolaena } \\
\text { odorata (L.) }\end{array}$ & Asteraceae & $\begin{array}{l}\text { Aqueous and } \\
\text { ethanolic }\end{array}$ & In vivo (rat) & $\downarrow$ Bleeding time & \multirow[t]{2}{*}{$\begin{array}{l}\text { Hemostatic, } \\
\text { wound healing }\end{array}$} & \multirow[t]{2}{*}{ (17) } \\
\hline $\begin{array}{l}\text { R.M.King \& } \\
\text { H.Rob. }\end{array}$ & & leaf extracts & In vitro & $\begin{array}{l}\uparrow \mathrm{PT} \\
\uparrow \mathrm{aPTT}\end{array}$ & & \\
\hline $\begin{array}{l}\text { Lamiophlomis } \\
\text { rotata (Benth. }\end{array}$ & Lamiaceae & $\begin{array}{l}\text { Aqueous } \\
\text { extract of }\end{array}$ & In vivo (mice) & & \multirow[t]{2}{*}{$\begin{array}{l}\text { Hemostatic, } \\
\text { wound healing }\end{array}$} & \multirow[t]{2}{*}{ (18) } \\
\hline ex Hook.f.) & & whole plant & In vitro & $\begin{array}{l}\downarrow \mathrm{TT} \\
\uparrow \text { Fibrinogen } \\
\text { No effect on PT \& aPTT }\end{array}$ & & \\
\hline $\begin{array}{l}\text { Ocimum } \\
\text { gratissimum L. }\end{array}$ & Lamiaceae & $\begin{array}{l}\text { Methanol } \\
\text { leaf extract }\end{array}$ & In vitro & $\begin{array}{l}\downarrow \text { PT } \\
\downarrow \text { aPTT } \\
\text { No effect on clotting time }\end{array}$ & Hemostatic & (19) \\
\hline $\begin{array}{l}\text { Panax } \\
\text { notoginseng } \\
\text { (Burkill) } \\
\text { F.H.Chen }\end{array}$ & Araliaceae & $\begin{array}{l}\text { Alcoholic } \\
\text { rhizome } \\
\text { extract }\end{array}$ & In vivo (rat) & $\downarrow$ Bleeding time & Hemostatic & $(20)$ \\
\hline $\begin{array}{l}\text { Paris } \\
\text { bashanensis } \\
\text { F.T.Wang \& } \\
\text { Tang }\end{array}$ & Melanthiaceae & $\begin{array}{l}\text { n-Butanol } \\
\text { extract of } \\
\text { rhizome }\end{array}$ & $\begin{array}{l}\text { In vivo (mice) } \\
\text { In vitro }\end{array}$ & $\begin{array}{l}\downarrow \text { Bleeding time } \\
\downarrow \text { Clotting time }\end{array}$ & Hemostatic & $(21)$ \\
\hline
\end{tabular}


J Pharm Pharm Sci (www.cspsCanada.org) 23, 11 - 23, 2020

\begin{tabular}{|c|c|c|c|c|c|c|}
\hline $\begin{array}{l}\text { Pelargonium } \\
\text { zonale (L.) } \\
\text { L'Hér. ex Aiton }\end{array}$ & Geraniaceae & Leaf juice & In vivo (rat) & $\downarrow$ Bleeding time & $\begin{array}{l}\text { Topical } \\
\text { hemostatic }\end{array}$ & $(22)$ \\
\hline $\begin{array}{l}\text { Psidium } \\
\text { guajava } \mathrm{L} .\end{array}$ & Myrtaceace & $\begin{array}{l}\text { Aqueous } \\
\text { leaf extract }\end{array}$ & $\begin{array}{l}\text { In vivo (rat) } \\
\text { In vitro }\end{array}$ & $\begin{array}{l}\text { No effect on bleeding time } \\
\uparrow \text { Platelet aggregation } \\
\uparrow \text { Vasoconstriction } \\
\uparrow \mathrm{PT} \\
\uparrow \mathrm{aPTT}\end{array}$ & Hemostatic & (23) \\
\hline $\begin{array}{l}\text { Pterocarpus } \\
\text { erinaceus Poir. }\end{array}$ & Fabaceae & $\begin{array}{l}\text { Ethanolic } \\
\text { stem bark } \\
\text { extract }\end{array}$ & In vivo (rat) & $\begin{array}{l}\downarrow \text { Bleeding time } \\
\text { No effect on clotting time }\end{array}$ & Hemostatic & $(24)$ \\
\hline $\begin{array}{l}\text { Scoparia dulcis } \\
\text { L. }\end{array}$ & Plantaginaceae & $\begin{array}{l}\text { Aqueous } \\
\text { decoction }\end{array}$ & $\begin{array}{l}\text { In vivo (rat) } \\
\text { In vitro }\end{array}$ & $\begin{array}{l}\downarrow \text { Clotting time } \\
\text { Procoagulant at low con. \& } \\
\text { anticoagulant at high conc. }\end{array}$ & $\begin{array}{l}\text { External } \\
\text { hemostatic }\end{array}$ & $(25)$ \\
\hline $\begin{array}{l}\text { Tagetes erecta } \\
\mathrm{L} .\end{array}$ & Compositae & $\begin{array}{l}\text { Aqueous } \\
\text { leaf extract }\end{array}$ & In vitro & $\downarrow$ PT & Wound healing & (26) \\
\hline $\begin{array}{l}\text { Tridax } \\
\text { procumbens } \\
\text { (L.) L. }\end{array}$ & Compositae & $\begin{array}{l}\text { Aqueous } \\
\text { leaf extract }\end{array}$ & $\begin{array}{l}\text { In vivo (rat) } \\
\text { In vitro }\end{array}$ & $\begin{array}{l}\downarrow \text { Bleeding time } \\
\downarrow \text { Clotting time }\end{array}$ & Hemostatic & $(27)$ \\
\hline $\begin{array}{l}\text { Typha latifolia } \\
\text { L. }\end{array}$ & Typhaceae & $\begin{array}{l}\text { Aqueous } \\
\text { pollen } \\
\text { extract }\end{array}$ & $\begin{array}{l}\text { In vivo (mice) } \\
\text { In vitro }\end{array}$ & $\begin{array}{l}\downarrow \text { Bleeding time } \\
\downarrow \text { PT } \\
\downarrow \text { aPTT } \\
\uparrow \text { FXII activity }\end{array}$ & $\begin{array}{l}\text { Internal \& } \\
\text { external } \\
\text { hemostatic }\end{array}$ & $(28)$ \\
\hline
\end{tabular}

Table 2. A summary of phytochemicals with positive in vivo or in vitro evidence on hemostasis.

\begin{tabular}{|c|c|c|c|c|c|}
\hline Phytochemical & Family & Derived plant & Study Type & Results & References \\
\hline $\begin{array}{l}\text { Browplasminin } \\
\text { (tannin) }\end{array}$ & Fabaceae & $\begin{array}{l}\text { Brownea grandiceps } \\
\text { Jacq. }\end{array}$ & In vitro & $\begin{array}{l}\text { Anti-fibrinolytic } \\
\text { (plasmin inhibitory effect) }\end{array}$ & (29) \\
\hline $\begin{array}{l}\text { 8-O-acetyl } \\
\text { shanzhiside } \\
\text { Methylester } \\
\text { (iridoid glycosides) }\end{array}$ & Lamiaceae & $\begin{array}{l}\text { Lamiophlomis rotata } \\
\text { (Benth. ex Hook.f.) } \\
\text { Kudo }\end{array}$ & In vivo (mice) & $\begin{array}{l}\downarrow \text { Bleeding time } \\
\downarrow \text { Blood loss } \\
\text { Anti-fibrinolytic } \\
\text { No effect on PT, aPTT and TT }\end{array}$ & $(30,31)$ \\
\hline Glycoconjugate & Lythraceae & Lythrum salicaria L. & $\begin{array}{l}\text { In vivo (rat) } \\
\text { In vitro } \\
\text { Ex vivo }\end{array}$ & $\begin{array}{l}\downarrow \text { Clotting time } \\
\uparrow \mathrm{aPTT} \\
\uparrow \mathrm{PT} \\
\uparrow \mathrm{TT}\end{array}$ & (32) \\
\hline $\begin{array}{l}\text { Lignan and phenolic } \\
\text { compounds }\end{array}$ & Myristicaceae & $\begin{array}{l}\text { Myristica fragrans } \\
\text { Houtt. }\end{array}$ & In vitro & Anti-fibrinolytic & (33) \\
\hline
\end{tabular}




\begin{tabular}{lllll}
\hline Saponins & Araliaceae & $\begin{array}{l}\text { Panax notoginseng } \\
\text { (Burkill) F.H.Chen }\end{array}$ & In vivo (rat) & $\downarrow$ Bleeding time \\
$\begin{array}{l}\text { Gallic acid, vanillic } \\
\text { acid, luteolin }\end{array}$ & Crassulaceae & Sedum aizoon L. & In vivo (mice) & $\downarrow$ Clotting time \\
& & In vitro & $\uparrow$ aPTT \\
& & & $\uparrow$ PT \\
& & & $\uparrow \mathrm{TT}$
\end{tabular}

aPTT, activated partial thromboplastin time; PT, prothrombin time; TT, thrombin time.

$\uparrow$ demonstrates increasing trend; $\downarrow$ demonstrates deccreasing trend.

\section{Ageratum conyzoides L. (Asteraceae)}

Ageratum conyzoides is a medicinal plant endemic to the parts of North and Central America with various indications in different diseases. Main uses of this plant in folk medicine is to treat colic, rheumatism, diarrhea, fever, wounds and bleeding $(12,36)$. Flavonoids, alkaloids, and tannins compose the main bioactive compounds of the $A$. conyzoides. The once a day administration of methanolic leaf extract of $A$. conyzoides $(250,500$, and $750 \mathrm{mg} / \mathrm{kg})$ in albino rats for two weeks resulted in the dose-dependent decrease of bleeding time, prothrombin time (PT) and clotting time. Also, plasma fibrinogen concentration considerably increased in favor of the hemostasis (12). Furthermore, the ethanolic extract of $A$. conyzoides leaf was able to reverse the antiplatelet and anticoagulant effects induced by aspirin, clopidogrel, and enoxaparin combination in mice. Aspirin and clopidogrel are thromboxane A2 inhibitors, while enoxaparin is factor $\mathrm{Xa}$ and thrombin inhibitor of intrinsic pathway. In test groups receiving $100 \mathrm{mg} / \mathrm{Kg}$ and $250 \mathrm{mg} / \mathrm{Kg}$ of ethanolic extract clotting time and bleeding time were significantly different from the negative control group (induction of drug combination only), and the $250 \mathrm{mg} / \mathrm{Kg}$ dose was able to reduce these values close to the normal values (no drug administration) (11). Both studies' results indicate the possible involving of intrinsic and extrinsic pathways in hemostatic activity of this medicinal plant $(11,12)$. With reference to the recent toxicological safety assessment of this extract, the effective hemostasis stimulating doses are safe. A. conyzoides, with 2000 $\mathrm{mg} / \mathrm{kg}$ body weight/day no observed adverse effect dose, did not show any toxicity or mortality in rats in the 90-day period of repeated oral administration. (37).

\section{Artemisia annua L. (Asteraceae)}

Artemisia annua, a Chinese medicinal plant, is characterized by the predominance of sesquiterpenoids and flavonoids. Artemisinin, a sesquiterpene which is famous for the potent antimalarial effect, is derived from this plant (38). Crude extract of $A$. annua was able to significantly reduce the in vitro clotting time of rabbit plasma by $8.51 \%$. Also, it was found that the n-butanol extract was more effective than the petroleum ether and ethyl acetate extract in shortening the clotting time. To distinguish the hemostatic active fraction of the extract the n-butanol extract was purified by polyamide and column chromatography of MCI gel. The resulting $20 \%$ methanol fraction after chromatography was determined as the active fraction responsible for the extract hemostatic effect with a $27 \%$ shortening rate of clotting time. Thus, evidences support the traditional use of this plant as a hemostatic drug (13). Acute toxicity studies of $A$. annua hydro-ethanolic extract, administered as the maximum dose of $5000 \mathrm{mg} / \mathrm{kg}$ body weight orally in mice, resulted in no mortal or toxic side effects (39). In addition, the 7-day oral administration of the plant tea infusion showed no adverse effects on Schistosomiasis patients (40).

\section{Brownea grandiceps Jacq. (Fabaceae)}

The infusion of Brownea grandiceps Flowers is used among Venezuelan women to decrease heavy menorrhagia. Secondary metabolites, including, tannins, saponins, flavonoids, alkaloids, carbohydrates, glycosides, and coumarins are present in the whole plant. The aqueous extract of $B$. grandiceps flowers (BGE) at low concentrations (250-1250 mg/mL) was found to shorten the human plasma PT. Also, the amidolytic activity of plasmin and tPA was decreased by all BGE concentrations tested in a dose- dependent manner (14).

Furthermore, the anti-fibrinolytic activity of BGE appears to be principally mediated by the active ingredient Browplasminin, which inhibits the plasmin activity in a dose-dependent manner. Browplasminin is a condensed tannin with 47.80 $\mu \mathrm{g} / \mathrm{mL}$ IC50 for plasmin. Although, this compound shows an inhibitory effect on the activity of plasmin, 
it has exhibited no decreasing effect on the activity of other serine-proteases such as trypsin, tPA or uPA (urokinase-type plasminogen activator) (29).

Despite the pro-coagulant effect of low BGE concentrations, $15000-25000 \mathrm{mg} / \mathrm{mL}$ concentrations exhibited anticoagulant activities by increasing PT, activated partial thromboplastin time (aPTT) and thrombin time (TT) (14). The inhibitory effect of Browplasminin on FXa is also observed by high concentrations (29). Overall, the low concentrations of $\mathrm{BGE}$ as tea infusion is recommended for the procoagulant and ant-fibrinolytic effect, resembling the infusion made in folk medicine for menorrhagia control.

\section{Camellia sinensis (L.) Kuntze (Theaceae)}

The green tea (Camellia sinensis) leaves, are the abundant source of polyphenols, mainly catechines, with prominent anti-oxidant activities. Caffeine, tannins, saponins and proteins are also present in the leaves (41). It was traditionally used to control bleeding because of its astringent effect. The ethanolic extract of green tea leaves has been shown to have positive effects on reducing the bleeding after tooth extraction. According to this randomized controlled trial, the use of green tea-soaked gauzes after tooth extraction significantly decreased the duration of socket bleeding from $10.09 \pm 3.61$ to 5.87 \pm 1.76 minutes. In addition, the number of oozing patients an hour post-surgery in green tea- treated group were less than the untreated group. These results are possibly attributed to the tannin content of the extract, which induces vasoconstriction on capillaries and blood coagulation (15).

According to the review by Bedrood et al, dermal application of high dose green tea extract may cause erythema in animals. Besides, the oral administration of the high dose extract or the main chemical constituents could develop several adverse effects considering the subject animal and the extract concentrations. Hepatotoxicity, gastrointestinal disturbances and with lower rates liver dysfunction and nervous system stimulation have been reported as the main observed side effects in experimental animals. There are controversial studies on the toxic effects of green tea on human, but the daily dose of $300 \mathrm{mg}$ Epigallocatechin gallate/person has been shown to be hepatic-safe (42).

Capsella bursa-pastoris (L.) Medik. (Brassicaceae) Capsella bursa-pastoris, the common name shepherd's purse, was traditionally used as a hemostatic herbal medicine in many countries especially Japan and China. Commonly, a tea prepared from the whole plant was used in internal organ hemorrhages such as stomach, kidney and uterus (10). C. bursa-pastoris was found to be effective in the control of early postpartum hemorrhage. The hydro-alcoholic extract of $C$. bursa-pastoris significantly reduced the mean amount of postpartum bleeding in women undergoing the vaginal delivery. The total of $5 \mathrm{~g}$ of C. bursa-pastoris hydro-alcoholic extract (sublingual drops) along with the oxytocin infusion was given to the intervention group. Tannins and flavonoids of $C$. bursa-pastoris, which compose the large portion of active ingredients, seems to mediate the anti-hemorrhagic effect through the contraction of uterus smooth muscles and the strong antioxidant activity, respectively (16). The therapeutic dose of the extract are 5-8 g/day, and no toxic effects have been reported in the mentioned range. Higher doses ( $>25 \mathrm{~g} /$ day) should be avoided because of the probable side effects (16).

\section{Chromolaena odorata (L.) R.M.King \& H.Rob. (Asteraceae)}

Chromolaena odorata, also known as "Siam weed", is a rapidly growing perennial herb native to Americas mainly Central and South America. The fresh leaves of $C$. odorata has been used traditionally to stop bleeding, as an anti-inflammatory and wound healing agent (43). Flavonoids, phenolics, tannins, saponins, terpenoides and alkaloids are the main phytochemicals of this plant. The in vivo reduction of bleeding time in rats has been exhibited by application of aqueous and ethanolic (50, 70 and 95\%) extracts of dried and fresh leaves to the wound site. Although the in vivo test confirmed the significant hemostatic activity of the plant extract, especially for the $70 \%$ ethanol extract, the in vitro $\mathrm{PT}$, aPTT and platelet aggregation tests have shown the conflicting results, which could be due to the inadequate content of the calcium or aggregatory and coagulatory active compounds (17).

According to the animal studies, oral administration of the high dose extract more than $538.5 \mathrm{mg} / \mathrm{kg}$ body weight could result in the pancreas induced toxicity and detrimental hepatic effects (4445), whereas $>250 \mathrm{mg} / \mathrm{kg}$ body weight doses evoked kidney toxicity and abnormality in the histology of the rat intestine (46).

Lamiophlomis rotata (Benth. ex Hook.f.) Kudo (Lamiaceae)

Lamiophlomis rotata is a perennial plant endemic to 
some regions of China. The main principle phytoconstituents of $L$. rotata are iridoid glycosides and flavonoids. Among Chinese people it was used as a well-known herbal medicine for wound healing and hemostatic purposes. The 3-day administration of $L$. rotata aqueous extract (LRAE) in mice $(2 \mathrm{~g} / \mathrm{kg})$ could decrease the tail bleeding time by $40 \%$. Furthermore, the 14-day administration of LRAE in rats $(3 \mathrm{~g} / \mathrm{kg})$ exhibited decreasing effects on TT, and increasing effects on fibrinogen, but had no effect on PT and aPTT levels. In addition, hepatic parameters in rats improved after this period, indicating the possible role of liver function in hemostatic activity (18). Further studies introduced the iridoid glycosides, specifically 8-O-acetyl shanzhiside methylester, as the responsible compound for the observed hemostatic effects of $L$. rotata. It seems that the inhibition of fibrinolytic system is the main mechanism of hemostatic action of this compound $(30,31)$.

The study of acute and sub-chronic toxicity of iridoid glycosides in rat revealed that diarrhea and hemolytic anemia were the main observed adverse effects. No observed adverse effect level for iridoid glycosides were reported $4.6 \mathrm{~g} / \mathrm{kg} /$ day in acute toxicity and $0.12 \mathrm{~g} / \mathrm{kg} /$ day in sub-chronic toxicity tests (47).

\section{Lythrum salicaria L. (Lythraceae)}

Lythrum salicaria is a flowering medicinal plant with the dominance of flavonoids and phenolics, mainly tannins (48). Due to the astringent nature, it was used in bleeding control, dysentery and wound healing conditions. The glycoconjugate isolated from flowering parts of the L. salicaria has been shown to exhibit a pro-coagulant effect in vivo by shortening the blood clotting time in rats. In contrast, ex vivo assays in rats, and in vitro assays of human plasma confirmed the anticoagulant activity of glycoconjugate by increasing the PT, aPTT and TT values. Thus, it seems like the hemostatic activity works through other factors of the blood such as platelets and has no effect on the coagulation process (32).

Unfortunately, there is not any individual study regarding the toxicological profile of L. salicaria, but in therapeutic doses no obvious adverse effects were observed (32).

\section{Myristica fragrans Houtt. (Myristicaceae)}

Myristica fragrans, a medicinal aromatic plant, is the primary source of spices nutmeg and mace. It is widely found in the tropical regions of the world, mainly Indonesia. The use of nutmeg and mace as an anti-inflammatory and analgesic agent was prevalent in folk medicine. Lignans, phenolics, flavonoids and terpens are the predominant active ingredients. The lignan and phenolic compounds isolated from the $M$. fragrans pericarp extract were found to have antifibrinolytic effect, activated by urokinase, more than $70 \%$. Furthermore, there was tendency to promote blood coagulation, indicated by PT, aPTT, TT and fibrinogen tests on rabbit plasma (33).

Myristicin is considered to be the main active compound of $M$. fragrans seed responsible for the toxic effects of the seed. The $5 \mathrm{~g}$ of $M$. fragrans seed powder ingestion, equivalent to the $1-2 \mathrm{mg}$ myristicin $/ \mathrm{kg}$, is reported as the toxic dose. Cardiovascular toxicity and neurotoxicity (mainly hallucination) are the important adverse effects following the abuse of seeds (49). Moreover, the $\mathrm{LD}_{50}$ (median lethal dose) of $M$. fragrans alkaloids extract in mice was $5.1 \mathrm{~g} / \mathrm{kg}$ body weight. The unstable gait, hypoactivity and dizziness were observed in overdosed animals (50). There was no evident study concerning the toxic effects of $M$. fragrans pericarp in animal or human.

\section{Ocimum gratissimum L. (Lamiaceae)}

Ocimum gratissimum, the African basil, is used in many ailments such as diarrhea, dysentery, and hemorrhoids by native people. The fresh juice of the leaves is known as a remedy for bleeding wounds in Nigeria (19). Alkaloids, flavonoids, saponins and tannins compose the major chemical constitutes of the plant (51). In one study the aqueous and methanol leaf extract of $O$. gratissimum was evaluated for the blood clotting activity. It was demonstrated that the methanol extract added plasma of normal and factor VIII deficient people had significantly shortened PT and aPTT values, whereas the aqueous extract had no effect on clotting time. Therefore, the presence of pro-coagulant polar compounds in the $O$. gratissimum is confirmed (19).

It was shown that aqueous extract of $O$. gratissimum $\geq 4.5 \mathrm{~g} / \mathrm{kg}$ body weight could exert toxic effects in albino rats, whereas in lower doses used by traditional practitioners no toxicological effects threatened the liver (52). Another study demonstrated that the 30-day administration of 450 and $800 \mathrm{mg} / \mathrm{kg}$ body weight of aqueous extract had decreasing effects on RBC (red blood cell), PCV (packed cell volume), platelets and neutrophil count, and increased WBC (white blood cell) and lymphocyte count in albino Wistar rats (53). 


\section{Panax notoginseng (Burkill) F.H.Chen (Araliaceae)}

Panax notoginseng or the Chinese ginseng is a precious medicinal plant native to the China. Saponins, flavonoids and polysaccharides comprise the main chemical constituents of the $P$. notoginseng roots. A series of important saponins have been isolated from $P$. notoginseng roots, including: ginsenosides, notoginsenosides, gypenosides and etc. It has a wide range of therapeutic applications, especially in cardiovascular system disorders, such as improving blood circulation and stagnation, and induction of blood coagulation. (54). The hemostatic effect of $P$. notoginseng root has been demonstrated in a rat bleeding model. The alcoholic extract of the roots exhibited significant hemostatic activity (20). Besides, the saponin extract derived from the roots had the significant inhibition rates on the bleeding time as well as the alcoholic extract. It is assumed that the majority of the hemostatic activity may be attributed to the saponin content of the root (34).

Based on animal studies, $P$. notoginseng at doses higher than $150 \mathrm{mg} / \mathrm{kg}$ body weight induced cardiac toxicity, also, hepatotoxicity and nephrotoxicity were observed at $450 \mathrm{mg} / \mathrm{kg}$ body weight dosage. Although there are limited study concerning the $P$. notoginseng toxicity in human, nausea, vomiting, and some allergic reactions such as pustules and fever were reported following the over-dosage or misuse of $P$. notoginseng preparations (55).

\section{Paris bashanensis F.T.Wang \& Tang (Melanthiaceae)}

Paris, a genus widely spread across Asia and Europe, is centralized with the most diversity in China. Some of the species of this genus are exerted in the composition of famous Chinese medicine, Yunnan Baiyao Powder, which is used in bleeding conditions. The hemostatic activity of n-Butanol extract of Paris bashanensis rhizome has been studied. It was shown that the $70 \%$ ethanol eluent of the n-Butanol extract had the greatest inhibition rates on the mice bleeding time and clotting time compared with the 50 and $30 \%$ eluents. The test was assayed after 5-day oral administration of the extracts. It was concluded that the hemostatic effect of the $70 \%$ eluent may be related to the high pennogenin saponins present in the extract (21).

While the ethanolic extract of $P$. bashanensis was introduced as the reason of hemostatic effect, it was shown that the higher doses of the extract induced hemolytic activity by Half of hemolytic degree $(\mathrm{HD})_{50}=1.2 \mathrm{mg} / \mathrm{ml}(56)$.

\section{Pelargonium zonale (L.) L'Hér. ex Aiton (Geraniaceae)}

Pelargonium zonale, geranium, is a wild ornamental plant indigenous to the South Africa. In traditional African medicine the crushed leaves of geranium are applied to the wound to stop the bleeding. Tannin geraniin is found abundantly in the geraniaceae family. Using the in vivo rat tail bleeding model the hemostatic effect of $P$. zonale has been demonstrated. The topical application of crushed leaves and leaf juice has shown 50 and $80 \%$ decrease in the bleeding time, respectively. Furthermore, the commercial hemostatic gelatin sponge had the resembling effect in reduction of bleeding time to the geranium leaf juice (22).

There is not a specified animal or human studies of $P$. zonale toxicity. Nevertheless, a few cases of contact dermatitis and sensitization were reported, which were mainly attributed to the geraniol content of the geranium essential oil (57).

\section{Psidium guajava L. (Myrtaceae)}

Psidium guajava, the common name guava, is native to Asia countries. Guava leaves are used as a hemostatic agent in China and Thailand (23). Flavonoids, triterpenic acids, tannins, saponins and coumarines contain the main phytochemicals of the leaves (58). It has been demonstrated that the aqueous extract of guava leaves had ambiguous effects on hemostasis. Topical application of guava extract had no effect on bleeding time in rats. In addition, PT and aPTT, indicating the blood coagulation mechanisms, increased. In contrary, the guava leaf extract was able to stimulate the vasoconstriction and in vitro platelet aggregation in a dose-dependent manner in favor of hemostasis process (23).

The different varieties of guava leaves aqueous extract caused no signs of organ toxicity or pathologic change when administered orally in rat. The $\mathrm{LD}_{50}$ of aqueous guava extract was determined to be more than $5000 \mathrm{mg} / \mathrm{kg}$ body weight in rat (59). Other studies also showed the safety of guava extract in therapeutic doses (60).

\section{Pterocarpus erinaceus Poir. (Fabaceae)}

Pterocarpus erinaceus is a small to medium tree, belonging to the west and central African savanna. The characteristic components of this plant include tannins, saponins, phenols and flavonoids. The indigenous people of savanna utilize the decoction of $P$. erinaceus bark to treat diarrhea, dysentery and bleeding control $(24,61)$. It was demonstrated that 
the ethanolic extract of stem bark had the ability to significantly decrease bleeding time, when administered orally to rats for a 30-day period of time $(200 \mathrm{mg} / \mathrm{kg})$. However, there was no significant decrease in clotting time values. In addition, it was shown that the oral use of the extract was safer $\left(\mathrm{LD}_{50}\right.$ value more than $5000 \mathrm{mg} / \mathrm{kg}$ body weight), when compared to the intraperitoneal injection. Due to the $\mathrm{LD}_{50}$ more than $5000 \mathrm{mg} / \mathrm{kg}$ body weight the extract is classified as the non-toxic substance, and is practically safe in therapeutic doses (24).

\section{Scoparia dulcis L. (Plantaginaceae)}

Scoparia dulcis is a flowering plant, considered as a weed, distributed through the many tropical and subtropical countries. It has several applications in different traditional medicines such as in diabetes, hypertension and urinary diseases $(24,62)$. In Sri Lanka the crushed plant is applied to the wounds to stop bleeding. Tannines, coumarins, saponins and phenols are characterized as the main chemical constituents. The pro-coagulant activity of $S$. dulcis was shown by in vivo and in vitro evaluations. The oral administration of the decoction in rats resulted in the significant reduction of clotting time in days 2 and 7. However, in vitro tests on goat blood showed the pro-coagulant activity at lower doses and anticoagulant activity at $100 \mathrm{mg} / \mathrm{kg}$ body weight dose. Furthermore, PT, aPTT and TT values were not affected after 2 days of oral decoction administration in rats (25).

Likewise, the outcomes of the acute and subacute toxicity tests of the main chemical compound of the extract, coixol, showed that $100 \mathrm{mg} / \mathrm{kg}$ dosage is safe in mice. No toxic effects on liver or kidney were observed after a 3-day oral administration (63).

\section{Sedum aizoon L. (Crassulaceae)}

Sedum aizoon, a perennial edible plant often known as aizoon stonecrop, is commonly found in China. Studies have reported the presence of flavonoids, terpenoids and alkaloids in this plant. S. aizoon is a valuable medicinal plant in various hemorrhagic conditions in traditional Chinese medicine. The ethyl acetate fraction of the plant demonstrated considerable hemostatic activity. Further isolation of active compounds from the ethyl acetate fraction confirmed the hemostatic activity of gallic acid, vallinic acid, and luteolin. The in vivo clotting time of the mice was significantly decreased following the abdominal injection of these compounds. Moreover, PT, aPTT and TT values reduced. Therefore, maybe the anti-hemorrhagic effect of S. aizoon is related to these compounds (35).

Despite the indication of $S$. aizoon in hemorrhage control, it should be noted that the use of this medicinal plant at high doses or for a long period of time could lead to the Hepatic venoocclusive disease. It was reported that the oral administration of $S$. aizoon decoction (300-900 g/day), for 3-21 days, were followed by the serious hepatic toxicity, indicated by hepatomegaly, abdominal pain, liver dysfunction, and ascites. The intensity of the symptoms were dose-dependently increased (64).

\section{Tagetes erecta L. (Compositae)}

Tagetes erecta, with the common name marigold, is an ornamental plant distributed widely all over the world. It is used in folk medicine for the treatment of skin disorders, kidney problems, muscular and ear ache. Phenolic compounds, flavonoids and carotenoids make the main active constituents of $T$. erecta. The blood clotting property of $T$. erecta aqueous leaf extract has been shown by PT test on the human plasma of normal and hyperglycemic samples. The PT values of both groups were significantly decreased in the presence of the $T$. erecta extract. It could be in a part due to the phenolic compounds, which are present in high amounts in this plant (26).

The evaluation of acute toxicity of $T$. erecta flowers aqueous extract in mice exhibited the $\mathrm{LD}_{50}$ more than $12.0 \mathrm{~g} / \mathrm{kg}$ body weight. The observed toxicities included piloerection, intestinal contortion and lethargy, which were all reversible in the absence of the extract (65). Furthermore, the lutein and its ester isolated from $T$. erecta flowers showed no hepatotoxicity or nephrotoxicity or histopathological changes in a 13 week oral administration (up to $400 \mathrm{mg} / \mathrm{kg}$ body weight) in rat (66). No individual study of $T$. erecta leaves toxicity were found.

\section{Tridax procumbens (L.) L. (Compositae)}

Tridax procumbens, the common name coatbuttons, is a flowering plant found in the hot and mild temperate regions through the world. This plant is known to arrest bleeding of the wounds among the Nigerian tribes. The hemostatic activity of $T$. procumbens aqueous leaf extract has been exhibited by in vivo and in vitro assays. Bleeding time in rats was decreased by $57 \%$ following the external application of the extract. Moreover, dose-dependent reduction of the clotting time was observed when the extract was added to the rat plasma. It is claimed that 
the blood coagulating effect of the T. procumbens could be mainly attributed to the heat-resistance inorganic molecules (27).

The investigation of ethyl acetate extract toxicity in rats indicated the $\mathrm{LD}_{50}$ of $2100 \mathrm{mg} / \mathrm{kg}$ body weight. After a 14-day intraperitoneal administration of extract, with the maximum dose of $800 \mathrm{mg} / \mathrm{kg}$ body weight, increase in some hepatic enzymes, erythrocyte and leucocyte count and PCV were noticed. Also, increased body weight and toxic effects on vessel endothelial, which lead to the hemorrhage, were observed at high dose levels (67).

\section{Typha latifolia L. (Typhaceae)}

Typha latifolia, the common cattail, is an aquatic plant distributed in diverse climate conditions. Pollen, derived from the $T$. latifolia male flowers, has an astringent nature and is known as a wellknown Chinese herbal medicine utilized in internal and external hemorrhagic conditions $(68,28)$. The anti-hemorrhagic activity of $T$. latifolia has been confirmed by in vivo and in vitro evaluations. The aqueous pollen extract not only decreased PT and aPTT levels in a dose-dependent manner, but it also coagulated the factor XII deficient human plasma. Furthermore, the activity of factor XII was increased in the presence of pollen extract. In addition, the bleeding time, following the oral administration of the extract in mice, and the blood loss, after topical application of the extract to the cut tail, was significantly reduced. It was concluded that some anti-hemorrhagic flavonoids, which could affect the platelets or vessels, were responsible for the decrease in bleeding time. Also, probably an acidic polysaccharide stimulated coagulation via the intrinsic pathway resulted in the external hemostatic effect (28).

There was no study of the toxicity or adverse effects of pollen Typhae use in human or animals.

\section{DISCUSSION}

The use of medicinal plants as a major part of natural remedies is widely increasing around the world (69). The ethnopharmacological use of medicinal plants in various disorders, diseases and injuries has motivated the researchers for inspecting the observed effects by scientific studies. The present review represented the hemostatic activity of several plants using the in vitro, in vivo or the clinical studies.

Prevalent tests for screening the hemostatic effect of plant extracts in this review include bleeding time and clotting time in vivo, PT, aPTT, $\mathrm{TT}$, plasma fibrinogen, and fibrinolytic activity in vitro, as well as determining the bleeding amount in clinical studies. The PT, aPTT and TT tests are widely used to recognize the deficiencies in extrinsic, intrinsic and common pathways of coagulation, respectively (70). Increased plasma fibrinogen levels often give rise to the thrombus formation (71).

The most frequently studied families of the plants include Compositae, Lamiaceae, Fabaceae, and Asteraceae. The majority of the plants are prepared in the form of aqueous or organic extracts of leaf, rhizome, flower, bark, pollen or the whole plant, and for some plants the active components are isolated.

Almost all mentioned plants have been utilized to control bleeding in traditional and folk medicines in different parts of the world. The oral administration of the extracts in human, rat, mice or rabbit, and the topical application of the extracts or poultices on bleeding site, in addition to injection in some cases are employed. A large number of studies contain the in vivo and in vitro assays, while there are only two clinical experiments which determine the bleeding amount in oral cavity or postpartum. Except for Psidium guajava L., the bleeding time was reduced in all studies following the oral intake or external application. In several cases the in vitro experiments showed the opposite results compared with the in vivo tests, such as for Chromolaena odorata, Psidium guajava, Lamiophlomis rotate, Lythrum salicaria, and Scoparia dulcis. This contradiction may be due to the pharmacokinetic and pharmacodynamic properties of an herbal or phytochemical, indicating that in vitro effects are not always extensible to human or in vivo experiments. The hemostatic activity of plant extracts is mainly attributed to several mechanisms, including coagulation stimulation via increasing the factor XII activity and plasma fibrinogen levels, the fibrinolysis inhibition, vascular or smooth muscle constriction and platelet aggregation. Ageratum conyzoides and Typha latifolia are the plants with the most in vivo and in vitro evidence of hemostatic activity.

It is propounded that the bioactive compounds which are often involved in the bleeding control are categorized as tannins, saponins, glycosides and other phenolics. Moreover, the anti-fibrinolytic effect of browplasminin (tannin), 8-O-acetyl shanzhiside methylester (iridoid glycoside) and lignin are confirmed. Other isolated hemostatic compounds include glycoconjugate from Lythrum 
salicaria, saponins from Panax notoginseng, and Gallic acid, vanillic acid and luteolin from Sedum aizoon. Based on the extraction method and solvent type the concentration and potency of active ingredients may differ (72).

Also, it should be implied that the pro-coagulant activity of several protease enzymes found in the plant lattices have been shown, however, these studies were not included in this review (73).

Medicinal plants are made up of various phytochemical compounds, which are responsible for their therapeutic effects and some adverse effects. It is imperative to remember that "natural" does not necessarily mean "safe". Practically all medicinal herbs could exert therapeutic effects at specific dose range and toxic effects at higher doses. As discussed in this review, plants including $B$. grandiceps, $P$. bashanensis, and $S$. dulcis exhibited procoagulant activity in low doses and anti-coagulant or fibrinolytic activity at higher doses. Likewise, $T$. procumbens destroys the vessel endothelial at high dosage administration and leads the hemorrhage. Green tea is another example which seems to be safe in all using conditions. Contentious consequences of consumption of green tea in human are available. But it is more likely to observe serious liver toxicity at high dosage or long term use of its preparations or supplements. Altogether, the most detrimental adverse effects of high dose administration of hemostatic plants are hepatotoxicity and nephrotoxicity. Other common unfavorable effects include gastrointestinal disturbances, neurotoxicity, change in hematologic factors, cardiac toxicity, and allergic reactions. Besides, there were no particular study concerning the toxicity profile of $L$. salicaria, $P$. zonale and T. latifolia.

Given all this, since traditional herbal preparations such as tea or decoction contain the low concentrations of the plant extract, the incidence of adverse effects are not prevalent following their use. However, if the extract has been concentrated or the active hemostatic ingredients have been isolated, the complete toxicity study should be performed before its use in human subjects.

\section{CONCLUSION}

Currently inevitable adverse effects and high costs of available hemostatic agents decrease the interest for their use. Based on the present review, there are several medicinal plants with the potential hemostatic activities that could be considered as the abundant sources of the new herbal-based drugs.
Although, further clinical studies are necessary to approve their safety and efficacy in human. Furthermore, the prepared list of plants could be practical in detecting the possible interactions of medicinal plants with anticoagulant, antiplatelet, fibrinolytic and antifibrinolytic medications.

\section{ACKNOWLEDGMENTS}

This work was funded by Tabriz University of Medical Sciences.

\section{CONFLICT OF INTEREST}

The authors declare no conflict of interest.

\section{ABBREVIATIONS}

aPTT, activated partial thromboplastin time; FXa, activated form of the coagulation factor X; FXII, factor XII; PT, prothrombin time; tPA, tissue plasminogen activator; TT, thrombin time; uPA, urokinase-type plasminogen activator.

\section{REFERENCES}

1. Beshir SA, Yap L Bin, Sim S, Chee KH, Lo YL. Assessment of predicted rate and associated factors of dabigatran-induced bleeding events in malaysian patients with non-valvular atrial fibrillation. J Pharm Pharm Sci, 2017; 20 (1): 365-377. Doi: 10.18433/J3TP9Q.

2. Golebiewska EM, Poole AW. Platelet secretion: from haemostasis to wound healing and beyond. Blood Rev, 2015. Doi: 10.1016/j.blre.2014.10.003.

3. Chapin JC, Hajjar KA. Fibrinolysis and the control of blood coagulation. Blood Reviews, 2015. Doi: 10.1016/j.blre.2014.09.003.

4. Binazon O, Dubois-Gaché A, Nanau RM, Neuman MG. Efficacy and safety of platelet inhibitors. J Pharm Pharm Sci, 2012. Doi: 10.18433/J3MP4Z.

5. Rau JC, Beaulieu LM, Huntington JA, Church FC. Serpins in thrombosis, hemostasis and fibrinolysis. J Thromb Haemostasis, 2007. Doi: 10.1111/j.15387836.2007.02516.x.

6. Mankad M.B.B.S PS, odispoti MC. The role of fibrin sealants in hemostasis. Am J Surg, 2001. Doi: 10.1016/S0002-9610(01)00773-5.

7. Bak JB, Singh A, Shekarriz B. Use of gelatin matrix thrombin tissue sealant as an effective hemostatic agent during laparoscopic partial nephrectomy. J Urol, 2004.2 Doi: 10.1097/01.ju.0000104800.97009.c6.

8. Levi MM, Vink R, de Jonge E. Management of bleeding disorders by prohemostatic therapy. Int $\mathrm{J}$ 
Hematol, 2002. Doi: 10.1007/BF03165104.

9. De Koninck P, Sarhan F, Mateescu MA, Archambault D, Hamel F. Carboxymethyl-Starch Excipients for Gastrointestinal Stable Oral Protein Formulations Containing Protease Inhibitors. J Pharm Pharm Sci, 2016. Doi: 10.18433/J3B01F.

10. Al-Snafi AE. The chemical constituents and pharmacological effects of Capsella bursa-pastorisA review. Int J Pharmacol Toxicol, 2015; 5(2):76-81.

11. Sukmawan YP, Suhendy H. Haemostatic effect of ethanolic extract of Ageratum conyzoides L. to strains of mice male swiss webster induced with combination of aspirin, clopidogrel and enoxaparin. Asian J Pharm Clin Res, 2017; 10(7):276. Doi: 10.22159/ajpcr.2017.v10i7.18573.

12. O.Bamidele. Haemostatic effect of methanolic leaf extract of Ageratum conyzoides in albino rats. J Med Plants Res, 2010.

13. Wang B, Sui J, Yu Z, Zhu L. Screening the hemostatic active fraction of Artemisia annua L. invitro. Iran J Pharm Res, 2011.

14. Pereira B, Brazón J. Aqueous extract from Brownea grandiceps flowers with effect on coagulation and fibrinolytic system. J Ethnopharmacol, 2015. Doi: 10.1016/j.jep.2014.11.022.

15. Soltani R, Haghighat A, Fanaei M, Asghari G. Evaluation of the effect of green tea extract on the prevention of gingival bleeding after posterior mandibular teeth extraction: A randomized controlled trial. Evidence-based Complement Altern Med, 2014. Doi: 10.1155/2014/857651.

16. Ghalandari S, Kariman N, Sheikhan Z, Mojab F, Mirzaei M, Shahrahmani H. Effect of Hydroalcoholic Extract of Capsella bursa-pastoris on Early Postpartum Hemorrhage: A Clinical Trial Study. J Altern Complement Med, 2017. Doi: 10.1089/acm.2017.0095.

17. Pandith $\mathrm{H}$, Thongpraditchote $\mathrm{S}$, Wongkrajang $\mathrm{Y}$, Gritsanapan W. In vivo and in vitro hemostatic activity of Chromolaena odorata leaf extract. Pharm Biol, 2012. Doi: 10.3109/13880209.2012.656849.

18. Li M, Jia Z, Hu Z, Zhang R, Shen T. Experimental study on the hemostatic activity of the Tibetan medicinal herb Lamiophlomis rotata. Phyther Res, 2008. Doi: 10.1002/ptr.2359.

19. Edemeka DBU, Ogwu AS. Blood Coagulation Activities of the Leaf Extracts of Ocimum gratissimum Plant in Man. J Herbs Spices Med Plants, 2000; 30;7(4):9-14. Doi: 10.1300/J044v07n04_02.

20. White CM, Fan C, Song J, Tsikouris JP, Chow M. An evaluation of the hemostatic effects of hydrophilic, alcohol, and lipophilic extracts of notoginseng. Pharmacotherapy, 2001. Doi: 10.1592/phco.21.9.773.34561.

21. Wang Y, Hao J, Gao W, Liu Z, Wu S, Jing S. Study on hemostatic activities of the rhizome of Paris bashanensis. Pharm Biol, 2013. Doi:
10.3109/13880209.2013.790065.

22. Páez X, Hernández L. Topical hemostatic effect of a common ornamental plant, the geraniaceae Pelargonium zonale. J Clin Pharmacol, 2003. Doi: 10.1177/0091270002251019.

23. Jaiarj $\mathrm{P}$, Wongkrajang $\mathrm{Y}$, Thongpraditchote $\mathrm{S}$, Peungvicha $P$, Bunyapraphatsara N, Opartkiattikul N. Guava leaf extract and topical haemostasis. Phyther Res, 2000. Doi: 10.1002/10991573(200008)14:5<388::AID-PTR638>3.0.CO;2-K.

24. Salawu A, Aliyu M, Ay T. Haematological studies on the ethanolic stem bark extract of Pterocarpus erinaceus poir ( fabaceae ). Afr J Biotechnol, 2008. Doi: 10.1111/j.1600-051X.2007.01184.x.

25. Ediriweera ERHSS, Jayakody JRAC, Ratnasooriya WD. Pro blood clotting activity of Scoparia dulcis in rats. Ayu, 2011. Doi: 10.4103/0974-8520.92547.

26. Dasgupta N, Ranjan S, Shree M, Saleh MAAM, Ramalingam C. Blood coagulating effect of marigold (Tagetes erecta L.) leaf and its bioactive compounds. Orient Pharm Exp Med, 2016. Doi: 10.1007/s13596015-0200-z.

27. Ikese CO, Okoye ZC, Kukwa DT, Adoga SO, Lenka JL. Effect of aqueous leaf extract of Tridax procumbens on blood coagulation. Int J Pharm Sci Res, 2015;6(8):3391.

28. Ohkura N, Tamura K, Tanaka A, Matsuda J, Atsumi GI. Experimental study on the hemostatc activity of Pollen Typhae: A traditional folk medicine used by external and oral application. Blood Coagul Fibrinolysis, 2011. Doi: 10.1097/MBC.0b013e328349a22c.

29. Pereira B, Brazón J, Rincón M, Vonasek E. Browplasminin, a condensed tannin with antiplasmin activity isolated from an aqueous extract of Brownea grandiceps Jacq. flowers. J Ethnopharmacol, $2017 . \quad$ Doi: 10.1016/j.jep.2017.01.012.

30. Li M, Zhang R, Jia Z, Sheng J, Qiu J, Wang J. Isolation and identification of hemostatic ingredients from Lamiophlomis rotata (Benth.) Kudo. Phyther Res, 2009. Doi: 10.1002/ptr.2669.

31. Fan PC, Ma HP, Hao Y, He XR, Sun AJ, Jiang W, et al. A new anti-fibrinolytic hemostatic compound 8O-acetyl shanzhiside methylester extracted from Lamiophlomis rotata. J Ethnopharmacol, 2016. Doi: 10.1016/j.jep.2016.04.016.

32. Pawlaczyk I, Czerchawski L, Kańska J, Bijak J, Capek P, Pliszczak-Król A, et al. An acidic glycoconjugate from Lythrum salicaria L. with controversial effects on haemostasis. J Ethnopharmacol, 2010.2 Doi: 10.1016/j.jep.2010.06.001.

33. Zhang Y, Xie P, Guo X, Kang W. Procoagulant Substance and Mechanism of Myristica fragrans. J Med Food, 2016. Doi: 10.1089/jmf.2016.3700.

34. White CM, Fan C, Chow M. An evaluation of the hemostatic effect of externally applied notoginseng 
and notoginseng total saponins. J Clin Pharmacol, 2000. Doi: 10.1592/phco.21.9.773.34561.

35. Lin Z, Fang Y, Huang A, Chen L, Guo S, Chen J. Chemical constituents from Sedum aizoon and their hemostatic activity. Pharm Biol, 2014. Doi: 10.3109/13880209.2014.895019.

36. Okunade AL. Ageratum conyzoides L. (Asteraceae). Fitoterapia, 2002. Doi: 10.1016/S0367326X(01)00364-1.

37. Palmer PA, Bryson JA, Clewell AE, Endres JR, Hirka $\mathrm{G}$, Vértesi A, et al. A comprehensive toxicological safety assessment of an extract of Ageratum conyzoides. Regul Toxicol Pharmacol, 2019. Doi: 10.1016/j.yrtph.2019.01.027.

38. Brown GD. The biosynthesis of artemisinin (Qinghaosu) and the phytochemistry of artemisia annua L. (Qinghao). Molecules, 2010. Doi: 10.3390/molecules 15117603 .

39. Siddiqui M, Waghmare SP, Hajare SW, Deshmukh RSISG, Ali SDCSA. Phytochemical analysis and acute toxicity studies of Artemisia annиa in Swiss albino mice. J Pharmacogn Phytochem, 2018;7(4):1893-5.

40. Munyangi J, Cornet-Vernet L, Idumbo M, Lu C, Lutgen $\mathrm{P}$, Perronne $\mathrm{C}$, et al. Effect of Artemisia annua and Artemisia afra tea infusions on schistosomiasis in a large clinical trial. Phytomedicine, 2018. Doi: 10.1016/j.phymed.2018.10.014.

41. Pan X, Niu G, Liu H. Microwave-assisted extraction of tea polyphenols and tea caffeine from green tea leaves. Chem Eng Process, 2003. Doi: 10.1016/S0255-2701(02)00037-5.

42. Bedrood Z, Rameshrad M, Hosseinzadeh H. Toxicological effects of Camellia sinensis (green tea): A review. Phytother Res, 2018. Doi: $10.1002 /$ ptr.6063.

43. Pandith H, Zhang X, Liggett J, Min K-W, Gritsanapan W, Baek SJ. Hemostatic and Wound Healing Properties of Chromolaena odorata Leaf Extract. Int Sch Res Not, 2013. Doi: 10.1155/2013/168269.

44. Asomugha RN, Okafor PN, Ijeh II, Orisakwe OE, Asomugha AL, Ndefo JC. Toxicological evaluation of aqueous leaf extract of chromolaena odorata in male wistar albino rats. J Appl Pharm Sci, 2013. Doi: 10.7324/JAPS.2013.31216.

45. Asomugha RN, Okafor PN, Ijeh II, Orisakwe OE, Asomugha AL. Hepatic effects of aqueous extract of Chromolaena odorata in male Wistar albino rats. Pharmacologyonline, 2014.

46. Anyanwu S, Inyang IJ, Asemota EA, Obioma OO, Okpokam DC, Agu VO. Effect of ethanolic extract of Chromolaena odorata on the kidneys and intestines of healthy albino rats. Integr Med Res, 2017. Doi: 10.1016/j.imr.2017.06.004.

47. Zhang Q, Mao Z, Zhang Q, Qiu J, Jia Z, Qin L. Acute and sub-chronic toxicological studies of the iridoid glycosides extract of Lamiophlomis rotata (Benth.)
Kudo in rats. Regul Toxicol Pharmacol, 2018. Doi: 10.1016/j.yrtph.2017.12.018.

48. Tunalier Z, Koşar M, Küpeli E, Çaliş I, Başer KHC. Antioxidant, anti-inflammatory, anti-nociceptive activities and composition of Lythrum salicaria L. extracts. J Ethnopharmacol, 2007. Doi: 10.1016/j.jep.2006.10.024.

49. N.A.A R, A F, M.E E. Toxicity of Nutmeg (Myristicin): A Review. Int J Adv Sci Eng Inf Technol, 2015. Doi: 10.18517/ijaseit.5.3.518.

50. Hayfaa AAS, Sahar AAMAS, Awatif MAS. Evaluation of analgesic activity and toxicity of alkaloids in Myristica fragrans seeds in mice. J Pain Res, 2013. Doi: 10.2147/JPR.S45591.

51. Edeoga HO, Omosun G, Uche LC. Chemical composition of Hyptis suaveolens and Ocimum gratissimum hybrids from Nigeria. J Biotechnol, 2006. Doi: 10.4314/ajb.v5i10.42928.

52. O.A O. Toxicity Studies of the Crude Aqueous Leaves Extracts of Ocimum gratissimum in Albino Rats. IOSR J Environ Sci Toxicol Food Technol, 2013. Doi: 10.9790/2402-0643439.

53. Aribo EO, Ofem OE, Moses ME. Prolonged Administration of Leaf Extract of Ocimum gratissimum Reduces RBC, PCV and Platelet Count but Increases Total WBC and Lymphocyte Counts in Rats. European J Med Plants, 2019. Doi: 10.9734/ejmp/2019/v27i230111.

54. Dong TTX, Cui XM, Song ZH, Zhao KJ, Ji ZN, Lo $\mathrm{CK}$, et al. Chemical assessment of roots of Panax notoginseng in China: Regional and seasonal variations in its active constituents. J Agric Food Chem, 2003. Doi: 10.1021/jf034229k.

55. Wang T, Guo R, Zhou G, Zhou X, Kou Z, Sui F, et al. Traditional uses, botany, phytochemistry, pharmacology and toxicology of Panax notoginseng (Burk.) F.H. Chen: A review. J Ethnopharmacol, 2016. Doi: 10.1016/j.jep.2016.05.005.

56. Liu Z, Li N, Gao W, Man S, Yin S, Liu C. Comparative study on hemostatic, cytotoxic and hemolytic activities of different species of Paris L. J Ethnopharmacol. 2012.2 Doi: 10.1016/j.jep.2012.05.065.

57. Lis-Balchin M. Geranium essential oil: standardisation, ISO; adulteration and its detection using GC, enantiomeric columns, toxicity and bioactivity. Geranium and Pelargonium: History of Nomenclature, Usage and Cultivation. CRC Press, 2003; 184 p. Doi: 10.1201/9780203216538.

58. Gutiérrez RMP, Mitchell S, Solis RV. Psidium guajava: A review of its traditional uses, phytochemistry and pharmacology. J Ethnopharmacol, 2008. Doi: 10.1016/j.jep.2008.01.025.

59. Babatola LJ, Oboh G, Ademiluyi AO. Toxicological evaluation of aqueous extract of different varieties of guava (Psidium guajava Linn) leaves. Comp Clin Path, 2019. Doi: 10.1007/s00580-019-03002-0. 
60. Daswani P, Gholkar M, Birdi T. Psidium guajava: A single plant for multiple health problems of rural Indian population. Pharmacogn Rev, 2017.

61. Gabriel AF, Onigbanjo HO. Phytochemical and Antimicrobial Screening of the Stem Bark Extracts of Pterocarpus erinaceus ( Poir ). Niger J Basic Appl, 2010.

62. Pari L, Latha M. Protective role of Scoparia dulcis plant extract on brain antioxidant status and lipidperoxidation in STZ diabetic male Wistar rats. BMC Complement Altern Med, 2004. Doi: 10.1186/1472-6882-4-16.

63. Sharma KR, Adhikari A, Hafizur RM, Hameed A, Raza SA, Kalauni SK, et al. Potent insulin secretagogue from Scoparia dulcis linn of nepalese origin. Phyther Res, 2015. Doi: 10.1002/ptr.5412.

64. Shao H, Chen HZ, Zhu JS, Ruan B, Zhang ZQ, Lin $\mathrm{X}$, et al. Computed tomography findings of hepatic veno-occlusive disease caused by Sedum aizoon with histopathological correlation. Brazilian J Med Biol Res, 2015. Doi: 10.1590/1414-431x20154563.

65. Martínez R, Diaz B, Vásquez L, Compagnone RS, Tillett S, Canelón DJ, et al. Chemical composition of essential oils and toxicological evaluation of tagetes erecta and tagetes patula from venezuela. J Essent Oil-Bearing Plants, 2009. Doi: 10.1080/0972060X.2009.10643747.

66. Harikumar KB, Nimita CV, Preethi KC, Kuttan R,
Shankaranarayana ML, Deshpande J. Toxicity profile of lutein and lutein ester isolated from marigold flowers (Tagetes erecta). Int J Toxicol, 2008. Doi: 10.1080/10915810701876265.

67. A. A. Acute And Sub Chronic Toxicity Of Tridax Procumbens In Experimental Animals. IOSR J Environ Sci Toxicol Food Technol, 2012. Doi: 10.9790/2402-0161927.

68. Mitich LM. Common Cattail, Typha latifolia L. Weed Technol, 2000; 14(2):446-50.

69. Halberstein RA. Medicinal plants: Historical and cross-cultural usage patterns. Ann Epidemiol, 2005. Doi: 10.1016/j.annepidem.2005.02.004.

70. Chitlur, M. Challenges in the laboratory analyses of bleeding disorders. Thromb Res, 2012. Doi: 10.1016/j.thromres.2012.03.011.

71. Doutremepuich, F., Aguejouf, O., Belougne-Malfatti, E., Doutremepuich, C. Fibrinogen as a factor of thrombosis: experimental study. Thromb Res, 1998; 90, 57-64. Doi: 10.1016/S0049-3848(98)00025-5.

72. Chukwumah Y, Walker L, Vogler B, Verghese M. Changes in the phytochemical composition and profile of raw, boiled, and roasted peanuts. J Agric Food Chem, 2007. Doi: 10.1021/jf0718771.

73. Shivaprasad H V, Rajesh R, Vishwanath BS. Hemostatic interference of plant latex proteases. SM J Clin Pathol, 2016; 1(1):1-7. 